\title{
Neoadjuvant radiotherapy of primary irresectable unicentric Castleman's disease: a case report and review of the literature
}

\author{
Iris AC de Vries ${ }^{1}$, Marjolein MS van Acht ${ }^{1}$, Thomas BJ Demeyere ${ }^{2}$, Marnix LM Lybeert ${ }^{3}$, Jean-Paul de Zoete ${ }^{1}$, \\ Grard AP Nieuwenhuijzen ${ }^{1 *}$
}

\begin{abstract}
Background: Castleman disease (CD) is a rare benign disorder characterised by hyperplasia of lymphoid tissue that may develop at a single site or throughout the body. The etiology of this disorder is unclear, although the histopathological presentation can be differentiated into a hyaline vascular variant, a plasma cell variant and a mixed variant. Clinically, it has been recorded that 3 manifestations of CD are characterized: a localized unicentric type, a generalized multicentric type and a mixed form. Surgery remains the main treatment for resectable unicentric $C D$, since removal of the large node is possible without further complications. No consensus has been reached concerning the most adequate treatment for irresectable unicentric CD.
\end{abstract}

Methods: Case report of a 67 year old woman.

Results: This report, describes the case of a 67-year-old woman with unicentric Castleman disease located in the right lower abdomen. The patient had symptoms of fatigue, dyspnoea and pain in the right lower abdomen. Computed tomography (CT)- examination revealed a tumour, which had grown to form a close relationship with the common iliac vessels and the sacral bone. A Laparotomy procedure revealed that the tumour was an irresectable mass. Neo-adjuvant radiotherapy (40 Gy) was administered in order to downsize the tumour. Six weeks later a new CT-scan revealed a major reduction of the tumour, which enabled a successful radical resection of the tumour to be performed. Histopathological analysis of the tumour showed the hyaline vascular type of CD.

Conclusions: Neo-adjuvant radiotherapy should be considered in case of an irresectable unicentric CD.

\section{Background}

In 1954, Benjamin Castleman described an unusual benign disorder that was characterized by hyperplasia of lymphoid tissue [1]. A couple of years later, Castleman et al [2] published more cases with benign massive growth of lymph nodes that is commonly referred to as Castleman's disease (CD). Flendrig et al [3] categorised two main types and one mixed variant of $C D$. Keller et al [4] defined these histopathological different patterns.

The first being a hyaline vascular type (HV), characterized by lymphoid follicular hyperplasia with involuted germinal centres, which are partly or totally replaced by deposit of hyaline material and transfixed by a radially penetrating vessel, characterized as a 'lolly pop'

\footnotetext{
* Correspondence: achgnn@cze.nl

'Department of Surgery, Catharina Hospital, Eindhoven, The Netherlands
}

structure. The second variant was defined as the plasma cell type (PC) with a follicular hyperplasia of hyperplastic, large germinal centres in which the interfollicular areas were occupied by large sheets of plasma cells.

Clinically a broad spectrum of manifestations of CD are described, ranging from an asymptomatic localized lymphadenopathy to a severe symptomatic multifocal or generalized lymphadenopathy [5]. A commonly used system to classify the heterogeneity of CD was proposed by McCarty et al in 1995 [6]. This made a distinction between the unicentric and the multicentric forms of disease. This classification correlates quite well with the histopathologically variants. As the HV type is mostly unicentric and the PC type and the mixed variant seem to be mostly multicentric $[7,8]$. 
$\mathrm{CD}$ has to be treated because of its progressive course associated with local involvement of surrounding structures or because of the systemic effects associated with the multicentric form such as fever, weight loss, excessive sweating, hemolytic anaemia, splenomegaly, oedema and neuropathy.

CD can also be associated with HIV infection, POEMS syndrome, amyloidosis, renal insufficiency and increased risk of lymphoma [5,9-11], these conditions necessitate diagnostic and therapeutic intervention.

Surgery is considered to be the most adequate therapy for unicentric resectable cases of $\mathrm{CD}$, as it seems to be curative in almost all of the cases [4,6,12-20]. Radiotherapy has also been described as a definitive treatment, however with a variable response rate [4,9,10,21-30].

No consensus has been reached concerning the most adequate treatment for irresectable CD. To our knowledge, neo-adjuvant radiotherapy to downsize primary irresectable $C D$ in order to achieve a radical surgical resection has not been described yet. This paper reviews the associated literature concerning the treatment of $\mathrm{CD}$ and describes a case history of an irresectable unicentric localisation of $\mathrm{CD}$ which was treated with neo-adjuvant radiotherapy and subsequent radical resection.

\section{Methods}

\section{Case presentation}

A 67-year-old woman with a history of hyperthyroidism, proptosis and anaemia was referred to the internal medicine department with complaints of weight loss, fatigue, dyspnea and pain in the right lower abdomen. Physical examination revealed a painful palpable mass in the right lower quadrant of the abdomen.

Ultrasonography of the abdomen showed a multicystic, solid structure in the right lower abdomen. Subsequent Computed Tomography (CT) imaging of the abdomen showed right ventrally of the body of the first sacral vertebrum a partly solid, partly cystic tumour of $71 \times 51 \mathrm{~mm}$ with oedematous infiltration of the surrounding adipose tissue and a close relationship with the common iliac artery and vein (figure 1A). Since the radiological aspect was initially presumed to be indicative of ovarian cancer, the patient was referred for gynaecological examination. Transvaginal ultrasound showed a polycystic structure on the right side. CA125 was normal. The patient underwent a staging laparotomy by the gynaecologist, revealing a normal uterus, normal ovaries and a fixed retroperitoneal tumour located to the right side of the aortic bifurcation. A surgeon oncologist was consulted, and because of the fixation and close relationship of the tumour to the iliac vessels and sacral bone, the tumour was regarded as primary irresectable and only an incisional biopsy was performed to obtain material for histological examination.
Histopathology from the specimen revealed lymphoid hyperplasia, atrophic germinal centers and radialy penetrating vessels (lollypop phenomenon) as seen in the HV variant of $C D$, (figure 2). A subsequent positron emission tomogram (PET)-scan revealed no signs of disseminated disease. There were no laboratory abnormalities and the HIV test turned out to be negative. Since the tumour was regarded irresectable, neo-adjuvant radiotherapy was proposed in order to downsize the tumour to achieve a radical surgical excision. Neo-adjuvant radiotherapy was delivered by means of a 4-field technique to a dose of $40 \mathrm{~Gy}$ in 20 fractions of $2 \mathrm{~Gy}$. Six weeks later a CT-scan, revealed a major downsizing with a maximal diameter of the tumour of $47 \mathrm{~mm}$, which was initially $72 \mathrm{~mm}$ (figure 1B). A subsequent laparotomy revealed a mobile tumour and a radical resection was performed without complications. An intraoperative boost (IORT) of 10 Gy was applied to the presacral resection surface. The patient recovered without complications and final histology showed a cystic residual localisation of $\mathrm{CD}$ of the $\mathrm{HV}$ type with free resection margins. At present, two years and 3 months after resection of the tumour no signs of recurrence have been detected.

\section{Discussion}

This report documents a unique case of a primary irresectable case of the HV unicentric type of CD which was treated with neoadjuvant radiotherapy and subsequent successful radical resection. To our knowledge, there is no report in the literature describing neoadjuvant radiotherapy as part of the treatment of unicentric CD.

The etiology of Castleman's Disease is unknown. However, $\mathrm{CD}$ is associated with other disorders such as HIV infection, POEMS syndrome, amyloidosis, renal insufficiency and increased risk of lymphoma [5,9-11]. Therefore specific systemic therapy related to the associated disorder is indicated. There is no consensus yet concerning the most adequate treatment for CD. Surgery is considered to be the most adequate therapy for unicentric cases of $C D$ as it seems to be curative in most of the cases [4,6,12-20]. Various strategies have been described in case of irresectable unicentric CD ranging from primary radiotherapy, incomplete resection [10] and chemotherapy [31].

Primary radiotherapy has been described in numerous case reports and small case series as one of the strategies for the treatment of both unicentric and multicentric forms of CD. Keller et al [4] however described that in 4 cases primary radiotherapy had only a minimal effect and concluded that radiotherapy alone was not effective. However, several cases have been reported with significant responses to primary radiotherapy, for 


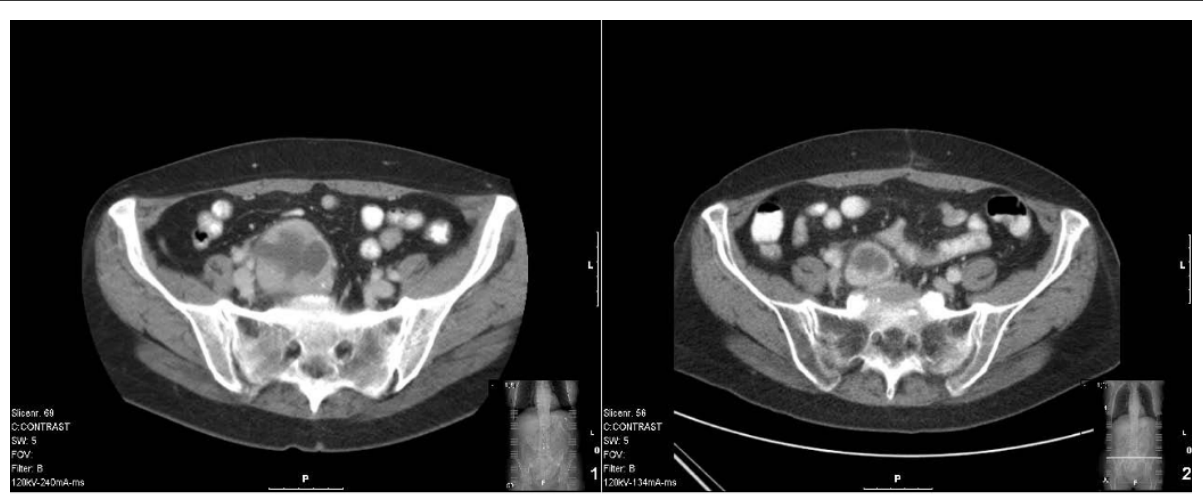

A

B

Figure $1 \mathrm{~A}$ : Computed Tomography (CT) of the abdomen showing the tumour and its relationship with the sacral vertebrum, the adipose tissue and the common iliac artery and vein, before neo-adjuvant radiotherapy. B: Computed Tomography (CT) of the abdomen showing the marked downsizing of the tumour, after neo-adjuvant radiotherapy.

the unicentric as well as for the multicentric form of CD $[9,10,21-23,25-30,32,33]$. Table 1, presents an overview of all studies that have evaluated the use of primary radiotherapy in $\mathrm{CD}$, both for unicentric and multicentric disease, with doses ranging from 12 to 50 Gy $[4,8-10,22-30,32,34,35]$. Responses to primary radiotherapy for the treatment of both forms of $\mathrm{CD}$ ranged from no response to a complete response. Nevertheless, $88 \%$ of all CD patients treated with radiotherapy showed a response, of which $43,8 \%$ showed a complete response.

With respect to the dose of radiotherapy, no correlation can be observed between dose and response. Most patients were treated with a dose between 40 and 50 Gy, however patients with a complete response received a dose between 12 Gy and 50 Gy.

The evidence in the current literature reveals that radical surgery results in excellent rates of cure

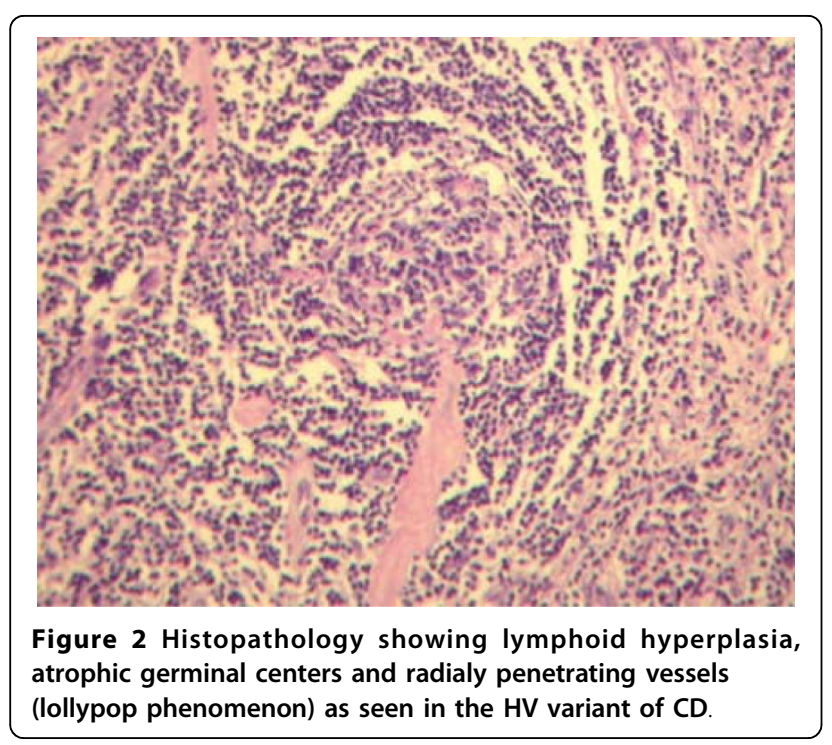

[4,6,12-19]. Also the literature reports excellent response rates with primary radiotherapy (table 1 ). Therefore it was concluded that, in case of an irresectable presentation of unicentric $C D$, surgery after neoadjuvant radiotherapy was a possible strategy. This case illustrates that this hypothesis was successful and should be considered as a strategy in case of irresectable unicentric disease. The question remains which policy should be followed in case of a complete radiologic response. Although merely speculative, a wait and see policy with regular radiological follow-up could be a reasonable strategy in case of no systemic symptoms, since most reports describe unicentric $C D$ as a slowly progressive disease, which does not metastasize. In the case where a recurrence of residual disease is found, a resection in an early stage could still be performed. In that case we propose a frequent follow up, using CT scanning every six months, since unicentric $C D$ is a slowly progressive disease. In case of a partial response to primary radiotherapy, we suggest that surgical resection is strongly recommended, since radical surgery can potentially cure unicentric $C D$.

Surgery was performed six weeks after the last radiotherapy dose. The rationale for this interval is based on the experience gained from treatments with other neoadjuvant strategies in solid tumours [36].

Different types of therapy have been described for the treatment of patients with multicentric CD. However the treatment strategy for this variant of $C D$ is not within the scope of this article. Nevertheless, the literature reveals that primary radiotherapy can also achieve a remission of symptoms $[10,24,26,28,30,32]$ and given the fact that multicentric $\mathrm{CD}$, more often then unicentric $\mathrm{CD}$, causes generalised symptoms, radiotherapy could also be used as a symptomatic treatment.

The rationale of our additional intra-operative radiotherapy (IORT) boost was based on the close 
Table 1 Summary of reports describing patients with CD treated with primary radiotherapy

\begin{tabular}{|c|c|c|c|c|c|}
\hline Reference & $\begin{array}{l}\text { Number of patients } \\
(\mathrm{n}=32)\end{array}$ & Histopathology & Type & Dose & Response \\
\hline \multirow[t]{2}{*}{ Fitzpatrick et al. (1968) } & 1 & - & Unicentric & 4500 & $P R$ \\
\hline & 1 & - & Unicentric & - & $C R$ \\
\hline Keller et al. (1972) & 4 & $\mathrm{HV}$ & Unicentric & $1800-4300$ & $\mathrm{PR}$ \\
\hline Emson et al. (1973) & 1 & - & - & 3500 & $P R$ \\
\hline Nordstrom et al. (1978) & 1 & PC & Unicentric & 2700 & $P R$ \\
\hline \multirow[t]{2}{*}{ Nordstrom et al. (1978) } & 1 & PC & Unicentric & 2700 & $P R$ \\
\hline & 1 & PC & Multicentric & 1500 & $P R$ \\
\hline Gaba et al. (1978) & 1 & $\mathrm{HV}$ & Multicentric & 4500 & $N R$ \\
\hline Weisenburger et al. (1979) & 1 & PC & Unicentric & 2700 & PR \\
\hline Marti et al. (1983) & 1 & M & Multicentric & 1200 & $C R$ \\
\hline Stokes et al. (1985) & 1 & PC & Unicentric & 3939 & $P R$ \\
\hline Sethi et al (1990) & 1 & $\mathrm{HV}$ & Unicentric & 4500 & $C R$ \\
\hline Massey et al. (1991) & 1 & M & Unicentric & 3040 & $P R$ \\
\hline Latz et al. (1992) & 1 & $\mathrm{HV}$ & Unicentric & 4000 & $C R$ \\
\hline Veldhuis et al. (1996) & 1 & PC & Unicentric & 4000 & $C R$ \\
\hline Bowne et al. (1999) & 1 & $\mathrm{HV}$ & Unicentric & 4500 & NR \\
\hline \multirow[t]{3}{*}{ Chronowski et al.(2001) } & 4 & $\mathrm{HV}$ & Unicentric & 4000 & $C R$ \\
\hline & 4 & $\mathrm{HV}$ & Unicentric & 3960 & $C R$ \\
\hline & 2 & $\mathrm{HV}$ & Unicentric & 3960 & $P R$ \\
\hline \multirow[t]{2}{*}{ Neuhof and Debus (2006) } & 1 & $\mathrm{HV}$ & Unicentric & $4000-5000$ & NR \\
\hline & 1 & $\mathrm{HV}$ & Unicentric & $4000-5000$ & $C R$ \\
\hline Neuhof and Debus (2006) & 1 & M & Unicentric & $4000-5000$ & NR \\
\hline All Reports & 32 & & & & $\begin{array}{l}\text { CR: } 14 / 32: 43,8 \% \\
\text { PR: } 14 / 32: 43,8 \% \\
\text { NR: } 4 / 32: 12,4 \%\end{array}$ \\
\hline
\end{tabular}

PC (plasma cell type); HV (hyaline vascular type); M (mixed HV and PC type); PR (partial response);

CR (complete response); NR (non response);

relationship with the sacral bone and iliac vessels and was analogous to our management of other locally advanced solid tumours like rectal cancer and soft tissue sarcomas [37-40].

\section{Conclusion}

In this case report it is demonstrated that neo-adjuvant radiotherapy in case of locally advanced irresectable unicentric CD facilitates a radical resection. Therefore, analogous with the treatment of other locally advanced solid tumours, neo-adjuvant radiotherapy with a dose of 40-50 Gy and a subsequent resection 6 weeks later should be considered if an irresectable unicentric variant of $\mathrm{CD}$ is encountered.

\section{Consent}

Written informed consent was obtained from the patient for publication of this case report and accompanying images. A copy of the written consent is available for review by the Editor-in-Chief of this journal.

\section{Author details}

'Department of Surgery, Catharina Hospital, Eindhoven, The Netherlands. 2Department of Pathology, Catharina Hospital, Eindhoven, The Netherlands. ${ }^{3}$ Department of Radiotherapy, Catharina Hospital, Eindhoven, The Netherlands.

\section{Authors' contributions}

IAC, MMS, GAP have made substantial contributions to conception and design, and acquisition of data and analysis and interpretation of data. IAC, MMS, T, MLM, JP, GAP have been involved in drafting the manuscript or revising it critically for important intellectual content. All authors read and approved the final manuscript.

\section{Competing interests}

The authors declare that they have no competing interests.

Received: 26 September 2009

Accepted: 2 February 2010 Published: 2 February 2010

\section{References}

1. Castleman B, Towne WW: Case records of the Massachusetts General Hospital; weekly clinicopathological exercises; founded by Richard C. Cabot. N Engl J Med 1954, 251(10):396-400.

2. Castleman $B$, Iverson $L$, Menendez VP: Localized mediastinal lymphnode hyperplasia resembling thymoma. Cancer 1956, 9(4):822-830.

3. Flendrig J: Benign giant lymphoma: clinicopathologic correlation study. Chicago: Yearbook Medical Publishers 1970, 296-299.

4. Keller AR, Hochholzer L, Castleman B: Hyaline-vascular and plasma-cell types of giant lymph node hyperplasia of the mediastinum and other locations. Cancer 1972, 29(3):670-683. 
5. Casper $\mathrm{C}$ : The aetiology and management of Castleman disease at 50 years: translating pathophysiology to patient care. Br J Haematol 2005, 129(1):3-17.

6. McCarty MJ, Vukelja SJ, Banks PM, Weiss RB: Angiofollicular lymph node hyperplasia (Castleman's disease). Cancer Treat Rev 1995, 21(4):291-310.

7. Dispenzieri A, Gertz MA: Treatment of Castleman's disease. Curr Treat Options Oncol 2005, 6(3):255-266.

8. Gaba AR, Stein RS, Sweet DL, Variakojis D: Multicentric giant lymph node hyperplasia. Am J Clin Pathol 1978, 69(1):86-90.

9. Bowne WB, Lewis JJ, Filippa DA, Niesvizky R, Brooks AD, Burt ME, Brennan MF: The management of unicentric and multicentric Castleman's disease: a report of 16 cases and a review of the literature. Cancer 1999, 85(3):706-717.

10. Chronowski GM, Ha CS, Wilder RB, Cabanillas F, Manning J, Cox JD: Treatment of unicentric and multicentric Castleman disease and the role of radiotherapy. Cancer 2001, 92(3):670-676.

11. Herrada J, Cabanillas F, Rice L, Manning J, Pugh W: The clinical behavior of localized and multicentric Castleman disease. Ann Intern Med 1998, 128(8):657-662.

12. Frizzera G: Castleman's disease: more questions than answers. Hum Pathol 1985, 16(3):202-205.

13. Frizzera G: Castleman's disease and related disorders. Semin Diagn Pathol 1988, 5(4):346-364

14. Humphreys SR, Holley KE, Smith LH, Mcllrath DC: Mesenteric angiofollicular lymph node hyperplasia (lymphoid hamartoma) with nephroitc syndrome. Mayo Clin Proc 1975, 50(6):317-321

15. LeVan TA, Clifford S, Staren ED: Castleman's tumor masquerading as a pancreatic neoplasm. Surgery 1989, 106(5):884-887.

16. Menke DM, Camoriano JK, Banks PM: Angiofollicular lymph node hyperplasia: a comparison of unicentric, multicentric, hyaline vascular, and plasma cell types of disease by morphometric and clinical analysis. Mod Pathol 1992, 5(5):525-530.

17. Seco JL, Velasco F, Manuel JS, Serrano SR, Tomas L, Velasco A Retroperitoneal Castleman's disease. Surgery 1992, 112(5):850-855.

18. Shahidi H, Myers JL, Kvale PA: Castleman's disease. Mayo Clin Proc 1995 70(10):969-977.

19. Shroff VJ, Gilchrist BF, DeLuca FG, McCombs HL, Wesselhoeft CW: Castleman's disease presenting as a pediatric surgical problem. $J$ Pediatr Surg 1995, 30(5):745-747

20. Martino G, Cariati S, Tintisona O, Veneroso S, De Villa F, Vergine M, Monti M: Atypical lymphoproliferative disorders: Castleman's disease. Case report and review of the literature. Tumori 2004, 90(3):352-355.

21. Gittinger JW Jr: Ocular involvement in Castleman's disease. Response to radiotherapy. Ophthalmology 1989, 96(11):1646-1649.

22. Latz D, Mende U, Schraube P, Rieden K: [The radiotherapy of Castleman's lymphoma]. Strahlenther Onkol 1992, 168(5):297-299.

23. Marti S, Pahissa A, Guardia J, Moragas A, Bacardi R: Multicentric giant follicular lymph node hyperplasia. Favorable response to radiotherapy. Cancer 1983, 51(5):808-810.

24. Massey GV, Kornstein MJ, Wahl D, Huang XL, McCrady CW, Carchman RA: Angiofollicular lymph node hyperplasia (Castleman's disease) in an adolescent female. Clinical and immunologic findings. Cancer 1991 68(6):1365-1372.

25. Neuhof D, Debus J: Outcome and late complications of radiotherapy in patients with unicentric Castleman disease. Acta Oncol 2006, 45(8):1126-1131.

26. Nordstrom DG, Tewfik HH, Latourette HB: Giant lymph node hyperplasia: a review of literature and report of two cases of plasma cell variant responding to radiation therapy. Int J Radiat Oncol Biol Phys 1978, 4(1112):1045-1048

27. Sethi T, Joshi K, Sharma SC, Gupta BD: Radiation therapy in the management of giant lymph node hyperplasia. Br J Radiol 1990, 63(752):648-650.

28. Stokes SH, Griffith RC, Thomas PR: Angiofollicular lymph node hyperplasia (Castleman's disease) associated with vertebral destruction. Cancer 1985, 56(4):876-879.

29. Veldhuis GJ, Leest van der AH, de Wolf JT, de Vries EG, Vellenga E: A case of localized Castleman's disease with systemic involvement: treatment and pathogenetic aspects. Ann Hematol 1996, 73(1):47-50
30. Weisenburger DD, DeGowin RL, Gibson P, Armitage JO: Remission of giant lymph node hyperplasia with anemia after radiotherapy. Cancer 1979, 44(2):457-462.

31. Dispenzieri A: Castleman disease. Cancer Treat Res 2008, 142:293-330.

32. Nordstrom DG, Tewfik HH, Latourette HB: Plasma cell giant lymph node hyperplasia responding to radiation therapy. AJR Am J Roentgenol 1978, 130(1):169-171.

33. Yoshida K, Suzuki T, Sakata T, Kawai N, Matsuda A, Kayano H, Hirashima K, Matsutani M, Bessho M: Successful treatment of multicentric Castleman's disease with intracranial and retroperitoneal tumors. Intern Med 2001 40(9):976-977.

34. Emson HE: Extrathoracic angiofollicular lymphoid hyperplasia with coincidental myasthenia gravis. Cancer 1973, 31(1):241-245.

35. Fitzpatrick PJ, Brown TC: Angiofollicular lymph node hyperplasia. Can Med Assoc J 1968, 99(25):1259-1262

36. Lim SB, Choi HS, Jeong SY, Kim DY, Jung KH, Hong YS, Chang HJ, Park JG: Optimal surgery time after preoperative chemoradiotherapy for locally advanced rectal cancers. Ann Surg 2008, 248(2):243-251.

37. Sadahiro S, Suzuki T, Ishikawa K, Yasuda S, Tajima T, Makuuchi $H_{4}$ Murayama C, Ohizumi Y: Intraoperative radiation therapy for curatively resected rectal cancer. Dis Colon Rectum 2001, 44(11):1689-1695.

38. Stitzenberg KB, Klauber-Demore N, Chang XS, Calvo BF, Ollila DW, Goyal LK, Meyers MO, Kim HJ, Tepper JE, Sartor Cl: In vivo intraoperative radiotherapy: a novel approach to radiotherapy for early stage breast cancer. Ann Surg Oncol 2007, 14(4):1515-1516.

39. Willett CG, Suit HD, Tepper JE, Mankin HJ, Convery K, Rosenberg AL, Wood WC: Intraoperative electron beam radiation therapy for retroperitoneal soft tissue sarcoma. Cancer 1991, 68(2):278-283.

40. Willett CG, Czito BG, Tyler DS: Intraoperative radiation therapy. J Clin Onco 2007, 25(8):971-977.

doi:10.1186/1748-717X-5-7

Cite this article as: de Vries et al:: Neoadjuvant radiotherapy of primary irresectable unicentric Castleman's disease: a case report and review of the literature. Radiation Oncology 2010 5:7.

\section{Submit your next manuscript to BioMed Central and take full advantage of:}

- Convenient online submission

- Thorough peer review

- No space constraints or color figure charges

- Immediate publication on acceptance

- Inclusion in PubMed, CAS, Scopus and Google Scholar

- Research which is freely available for redistribution 